\title{
Empathy as resistance in an age of protest: Turning the other cheek
}

\begin{tabular}{|c|c|}
\hline $\begin{array}{l}\text { Author: } \\
\text { Yolanda Dreye }\end{array}$ & $r^{1}$ (D) \\
\hline $\begin{array}{l}\text { Affiliation: } \\
{ }^{1} \text { Department } \\
\text { Theology, Facu } \\
\text { and Religion, } \\
\text { Pretoria, Soutl }\end{array}$ & $\begin{array}{l}\text { f Practical } \\
\text { Ity of Theology } \\
\text { Jniversity of } \\
\text { Africa }\end{array}$ \\
\hline $\begin{array}{l}\text { Research Proj } \\
\text { Project Leade } \\
\text { Project Numb }\end{array}$ & $\begin{array}{l}\text { ct Registration: } \\
\text { : Y. Dreyer } \\
\text { er: } 2546930\end{array}$ \\
\hline $\begin{array}{l}\text { Description: } \\
\text { This research } \\
\text { project, 'Gend } \\
\text { Practical Theo } \\
\text { Formation', di } \\
\text { Dr Yolanda Dr } \\
\text { Department o } \\
\text { Theology, FacL } \\
\text { Theology, Uni } \\
\text { Pretoria. }\end{array}$ & $\begin{array}{l}\text { s part of the } \\
\text { er Studies and } \\
\text { logy Theory } \\
\text { ected by Prof. } \\
\text { eyer, } \\
\text { f Practical } \\
\text { Ity of } \\
\text { ersity of }\end{array}$ \\
\hline $\begin{array}{l}\text { Correspondin } \\
\text { Yolanda Dreye } \\
\text { yolanda.dreye }\end{array}$ & $\begin{array}{l}\text { author: } \\
\text { r, } \\
\text { r@up.ac.za }\end{array}$ \\
\hline $\begin{array}{l}\text { Dates: } \\
\text { Received: } 12 \text { S } \\
\text { Accepted: } 24 \\
\text { Published: } 15\end{array}$ & $\begin{array}{l}\text { ept. } 2018 \\
\text { ept. } 2018 \\
\text { Vov. } 2018\end{array}$ \\
\hline $\begin{array}{l}\text { How to cite th } \\
\text { Dreyer, Y., } 201 \\
\text { as resistance i } \\
\text { protest: Turnir } \\
\text { cheek', HTS Te } \\
\text { Studies/Theol } \\
74(4) \text {, a5264. } \\
\text { org/10.4102/ }\end{array}$ & $\begin{array}{l}\text { is article: } \\
8 \text {, 'Empathy } \\
\text { an age of } \\
g \text { the other } \\
\text { logiese } \\
\text { gical Studies } \\
\text { tttps://doi. } \\
\text { ts.v74i4.5264 }\end{array}$ \\
\hline $\begin{array}{l}\text { Copyright: } \\
\text { (C) 2018. The A } \\
\text { Licensee: AOS } \\
\text { is licensed unc } \\
\text { Creative Comr } \\
\text { Attribution Lic }\end{array}$ & $\begin{array}{l}\text { uthors. } \\
\text { S. This work } \\
\text { ler the } \\
\text { nons } \\
\text { ense. }\end{array}$ \\
\hline Read online: & \\
\hline 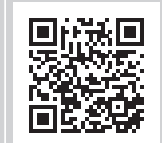 & $\begin{array}{l}\text { Scan this QR } \\
\text { code with your } \\
\text { smart phone or } \\
\text { mobile device } \\
\text { to read online. }\end{array}$ \\
\hline
\end{tabular}

In today's 'age of protest', people have the right to publically resist what they perceive to be unjust and abusive. Sometimes, public protest is non-violent, but often it becomes destructive. People get hurt and property is damaged. Those who have the least are often affected most. This article explores the potential of the centuries old ethics of the Jesus tradition coupled with recent insights from psychology on empathy, for effective and necessary resistance against injustice and power abuse, but without the futility of the violence and destruction. This way of love resists all evil, oppression and injustice, and has the power to break the spiral of violence.

\section{Introduction: From an 'age of innocence' to an 'age of protest'}

Over against eras such as 'The Age of Innocence' as portrayed in the film by that name, where New York's high society in the late 1800s was extremely polite, 'civilised' and proper, while perpetrating a quiet, well-hidden violence against the other if she (the character played by Michelle Pfeiffer) does not fit in and tow the line, and the similarly upright, conservative, correct 'Biedermann' in Europe, a heritage that reached far beyond the Biedermeier Era (1815-1848), whose covert and psychological violence was exposed by Freud, ours is an era of overt resistance. Recent events across the world attest to this.

Today it is acceptable and regarded as people's right to make their voices heard. The recent \#FeesMustFall movement among South African students was their way of resisting the everincreasing costs of tertiary education (see Buttelli \& Le Bruyns 2017). Buildings were torched, with libraries a specific target. Already scarce resources were destroyed and there are not sufficient funds to replace them. People were hurt, property damaged and students, who had paid hard-earned money for their education, had their examinations disrupted. They struggled to complete the academic year. In the United States, a president was elected, directly after which people took to the streets in large numbers to protest. In Germany, the host city of Hamburg was turned into a veritable war zone during the G 20 Summit in July 2017. Protesters destroyed and looted property, and people were hurt. The struggling police force who were there to serve and protect were not up to the task.

In this 'Age of Protest', this article explores the potential of the centuries old ethics of the Jesus tradition coupled with recent insights from psychology on empathy, for effective and necessary resistance against injustice and power abuse, but without the futility of the violence and destruction that often accompany such resistance.

The source of Christian ethics is the words and deeds of Jesus of Nazareth. Some of his injunctions are met, even by devoted followers, with a measure of uncertainty: 'Is it possible in practice? We are only human'. That is especially the response to 'turning the other cheek', praying for the enemy and blessing those who persecute you.

In this post-everything era, the ideal is to hear silenced voices into speech, as Nelle Morton (1977:4) famously put it, to empower, to resist abuse and injustice, rather than to 'turn the other cheek'. However, this would depend on how the injunction of Jesus is understood. If taken at face value and interpreted to mean compliance with violence and the abuse of power rather than resistance for a better outcome, then Jesus' words and the Christian ethics that developed from that would not be welcomed today. However, with a deeper understanding of the sociocultural context, the intended meaning of these words and the spirituality and ethics that subsequently developed, it could well be of great value even, and maybe especially, today.

The article argues that turning the other cheek in the deeper sense of its meaning is a form of resistance that can be utterly effective. This attitude of spirituality in the field of religion is brought 
into conversation with the attitude of empathy, much discussed in the field of psychology. The contention is that the combination of the two can become a form of resistance that not only lacks the negative effects of violence, but also has a powerful positive potential for peace-making and human flourishing. Firstly, from a psychological perspective, empathy will be explored. Secondly, from a religious and spiritual perspective, the potential of Christian ethics as established by Jesus and applied by Paul will be investigated. Thirdly, they will be brought into dialogue in order to discover their combined potential for constructive resistance and human flourishing.

\section{Empathy as interactional knowing}

In search of an English translation for the German Einfühlung, Titchener (1909; see Coplan 2011:41) coined the word 'empathy' from the Greek empatheia. The German Einfühlung, from the field of aesthetics, literally means 'to feel into'. In aesthetics, Einfühlung was about the emotion evoked by an artwork and the person 'feeling into' the object (see Blechner 1988:303). This 'feeling into' was applied to interrelationships by Lipps (1913). While aesthetics Einfühlung is a one-way process from the person to the artwork, in interrelationships it is a two-way, reciprocal process. Freud (1913a:140) used Einfühlung to describe how rapport can be established. Einfühlung, then, is a 'particular way of bringing oneself closer to another's experience' (see Freud 1913b:189).

With the insights of neurophysiology, 'the possibility of feeling thinking one's way into another's emotional state' becomes plausible, though Aragno (2008:719) cautions that the emotions felt in the process of empathetic Einfühlung are not the emotions of the other, but rather of the listenerempathiser. Basch (1983:105) points out that the listener does not identify with the person of the other, but rather with the experience. This attitude, disposition or way of interacting can be described as participatory involvement. Shared feeling creates proximity. On the other hand, cognitive thinking, which is also a part of the process, creates a certain distance. Empathy can therefore be described as a combination of participating in experience and cognitive understanding (Aragno 2008:723-724). It involves all of a person's faculties (see Schwaber 1984:160), the perceptual, sensory-emotive, cognitive and linguistic. Empathy and rationality are not opposites. Their interplay is important to the process of knowing and understanding.

Though there is wide consensus that empathy, 'that baseline, benevolent disposition that enables us to "put ourselves in others" emotional shoes in order to understand them', is central to good human relations and meaningful listening, investigations as to what the phenomenon entails have been surrounded by controversy (Aragno 2008:713; see Buie 1981; Shapiro 1981; Shevrin 1978; Stern 1994). Empathy has been interpreted in various ways, and not always positively.

From an epistemological perspective, empathy is a way of knowing unlike any other. It is a way to gain knowledge about the unique experiences of another (Blechner 1988:301). 'Knowing' is no longer limited to rational ways of knowing, but emotional intelligence, emotional cognition, has become recognised as a legitimate source for understanding human experience. Empathy denotes a dynamic process, namely 'a way of interacting, of putting oneself in another's emotional experience, a mode of apprehending another person's feelings. Empathy is empathizing' (Aragno 2008:714). On the positive side of the empathy controversy, it can be described as 'resonating with another's experience'.

More negative descriptions of empathy include 'projecting into, or attributing one's own experience to the other', also known as the 'pathetic fallacy' (Webster's 1966:57). Aragno (2008:718) criticises the long tradition of explaining empathy as identification, a capacity 'innate' to being human (see Bachrach 1976; Fliess 1942; Furer 1967). Though empathy as an epistemological process is useful as a way of knowing, a potential negative is also that the knowledge gained through this means can be misused to exploit or manipulate others (Blechner 1988:307). Another danger is that, even with the best intentions, excessive empathy can be harmful (see Modell 1979). Empathy is not always an appropriate response to the feelings and experiences of the other, such as when those are self-denigrating or self-destructive. A safeguard against inappropriate empathy would be to ask logical and critical questions with regard to what is expressed by the other, rather than just 'feeling into' it (Blechner 1988:308). If empathy has an epistemological function as a way of knowing, it cannot only be about immersion in the experience, but will also include examining that immersion. This applies to all the methods of knowing. With both sides of the argument taken into account, it is the source and the accuracy of empathetic understanding that will determine whether it has value or is a fallacy.

The evolutionary trajectory of the development of empathy is from signal (biological) to sign (indicating or referring to something), to symbol (something that stands for something else). In early life, imitation and mimicking are the response of the whole body to what is observed. Later, this evolves to the response to subtle and faint neurophysiological trace signals (see Langer 1967:176). This complex response involves focus and attention, feelings and thought. Though the origins of empathy lie in an automatic response to the affect clues that are observed in the other, in its more mature form, it provides information about the experience of the other. It creates 'correspondence with another's experience without the empathizer necessarily participating in the other's feelings' (Aragno 2008:732).

In the literature, a distinction is made between primary empathy and mature empathy. Aragno (2008:725) further distinguishes between ordinary, spontaneous mature empathy and the specialised use of mature empathy, for example, for the purposes of therapy. The difference is that the natural empathic reaction 'reacts to perceptual, auditory, and sensory-emotive cues', whereas the trained therapist responds to the semiotic, the meanings in communication, 
and interprets those meanings (Aragno 2008:731). This article is interested in the potential of ordinary mature empathy, not only as a spontaneous and unconscious response but also as interpreting meanings, combined with mature spirituality, to counteract the human tendency towards resistance as violence, vengeance and retribution, which most often results in needless destruction.

Mature empathy enables the listener to form an idea of the other's experience through a response in oneself generated by the other. This process relies on the flow of emotional information on an unconscious level through communication. The richness of empathetic understanding is that it enlarges the scope of one's own experience and general understanding. Through understanding, the experience of the other is interpreted. Empathy communicates 'interest, acceptance, compassion, tolerance, respect, forbearance, understanding, closeness, separateness' (Aragno 2008:733). It can contribute to creating a safe space and facilitating open communication. In a safe empathic space, difficult emotions can surface and receive the necessary attention. The quality of empathic attention can also be 'inherently freeing, growth-promoting, and emotionally maturational' (Aragno 2008:734). Empathic attunement makes it possible to reach the depths of the other's emotional experience beyond what is communicated on the surface.

Deonna (2007:99-101) identifies two conditions necessary for empathy: awareness of the other's emotions and feeling in tune with them. These should occur together to be proper empathy, because awareness without empathising, and feeling in tune with emotions without empathising with them, are both possible. Awareness is a cognitive activity. Therefore, proper empathy differs from identification, which is only about emotional sharing and simulation. By clarifying what is not empathy, Deonna (2007:103-112) describes what proper empathy entails. He dismisses the parallel model, where the empathiser and the other feel something similar, as not real empathy. According to the oscillation model, the empathiser's emotions oscillate rapidly between the own and the other's. This is closer to empathy, but is also not real empathy. When the emotions of the other function only as a stimulus for the emotions of the empathiser, it is no more than identification, which is the starting point for simulation. For identification, understanding alone is sufficient. Simulation is when the empathiser witnesses a situation, steps into the other's shoes, and discovers that they would feel the same in a similar situation. This involves 'making use of oneself as a model to then predict the other person's emotion and/or behaviour. This is very different from empathy', concludes Deonna (2007:109), because the experience of the other is just a trigger for the experience of the observer. Empathy also differs from contagion (emotional sharing), where a similar kind of emotion is triggered in the other. In order to be truly empathetic the experiences need not be identical. If the emotion of the other is experienced as one's own, it is a collapse into emotional contagion (Deonna 2007:111).
Proper empathy is the genuine recognition of the other's emotion. The empathiser experiences an emotion, which is similar, but also different. Deonna (2007:115) explains it as that 'empathizing proper specifies only partially the contents of the mind of the empathizer when empathizing'. This makes it possible for the empathiser to react differently. In the case of contagion, the reaction would be the same.

Blechner (1988:304-305) differentiates between a 'narrow definition' and a 'broad definition' of empathy. The narrow understanding points to something little more than contagion: an emotion in the one person evokes a similar emotion in the other. This has been called 'not-empathy' by some (see Sullivan 1953:41; Weigert 1962). The contagion way of 'feeling into' is irrational and even potentially destructive.

In the broader understanding of the term, on the other hand, stress in the one does not only evoke stress in the other, but rather serves as a signal for the other to do something to help alleviate the stress. In the broad understanding, empathy is not only about resonating with the emotion of the other, but also overcoming it with a constructive act (see Arlow 1979: 64-69). Ferenczi ([1928]1980:100) distinguishes between Einfühlung [feeling into] and Abschätzung [assessing or appraising what has been felt]. Kohut (1971:303) describes a similar process with the terms 'comprehension' and 'insight'. Recently, the broad view of empathy has gained popularity and proponents such as Frans De Waal (2009; see also Hoffman 2000; Stueber 2006) understand it as an umbrella concept.

Coplan (2011:43-44) opts rather for a narrower understanding of empathy. She differentiates between emotional contagion, pseudo-empathy and proper empathy. Pseudo-empathy is understood as 'a process of self-oriented perspective taking', and proper empathy is understood as 'a complex imaginative process through which an observer simulates another person's situated psychological states while maintaining clear self-other differentiation'.

Emotional contagion arises from a different neural system (see Preston \& De Waal 2002:1-20) than the neural system underlying proper empathy. Though contagion does provide access to the emotions of others, to feeling their experience, it does not contribute to an understanding of the experience. Pseudo-empathy is a self-oriented perspective over against the other-oriented perspective of proper empathy (Coplan 2011:53).

The way in which access to the emotions and experience of the other is gained determines the quality of understanding. The self-oriented path is by imagining from one's own point of view, how 'I' would think and feel in a similar situation. From an other-oriented perspective, one would imagine from the other's point of view how it would feel if you were the other in that situation. Coplan (2011:54) points out that otheroriented perspective taking is a different type of process than self-oriented perspective taking. The difference is not purely 
conceptual, but lies in the process itself. Other-oriented perspective taking 'requires greater mental flexibility and emotional regulation and often has different effects' (Coplan 2011:55; see Batson et al. 2003; Decety 2006). Neuroscience has shown that even the neural route of the two orientations differs (see Jackson et al. 2006; Ruby \& Decety 2001). Coplan (2011:55-56) concedes that it will be difficult to completely avoid a self-oriented perspective. Most probably, there will always be a measure of back and forth movement between the two orientations. However, for proper empathy to be possible, it is necessary that the empathiser focuses solely or mostly not only on the self, but also on the other. 'False consensus' takes place when the self-perspective does not sufficiently make way for the perspective of the other (Hodges \& Wegner 1997:311-339).

From a self-oriented perspective, one's own beliefs and values detract from understanding the experience of the other in a meaningful way. The greater danger lies not only in a lack of understanding, but also in the assumption that one understands and has access to the other's points of view, emotions and experiences, when in actual fact that is not the case. This is what Coplan (2011:56) calls 'pseudo-empathy'. She finds that it is better to acknowledge a lack of understanding and empathy than for them to be less than genuine.

The orientation of the empathetic person is also important when the other's distress causes the observer to also become distressed. There is a difference between when the focus remains on the other amid feelings of own distress, or whether the focus reverts to the self and becomes personal distress. With the focus then turned to the self, the empathiser will want to alleviate the own discomfort and escape from the situation and the other (Coplan 2011:57); see Decety \& Lamm 2009:199-213). Genuine and accurate empathy is possible only when the self-perspective is not dominant and the emotions of the other remain the emotions of the other. Therefore, Coplan (2011:58) sees proper empathy as 'a process through which an observer simulates another's situated psychological states while maintaining clear self-other differentiation'. Through this process, one can gain a genuine understanding of the other. However, it is not easy to achieve. To maintain an other-oriented perspective requires effort and self-regulation. It is 'a motivated and controlled process, which is neither automatic nor involuntary and demands that the observer attend to what is relevant' (Coplan 2011:58). This contrasts with the unregulated process of contagion.

\section{Empathy as resistance}

In our 'age of resistance', the main focus is resistance against political power and the injustices and abuses perpetrated by the powers that were (colonisers) and the powers that be. In response to this 'imperial hubris', literature educator Lisa Taylor (2007:297-316) develops reading practices to resist 'the slow acculturation of imperialism' (Spivak 1996:248). In projective empathy (Verducci 2000:63-80) and passive empathy (Boler 1999), the empathiser focuses on sameness while negating difference (see Taylor 2007:306). In such a 'projection of the self onto the other', the empathiser judges the other's actions and possibilities (Britzman 1998:83). It can lead to moral judgement of the other and the situation. This mode of 'empathy' is closer to identification than proper empathy and, in effect, colonises the other. In order to avoid it, a willingness to embrace and engage with alterity is needed. The otherness of the other and the difference of experience and emotion should be recognised and respected (see Taylor 2007:307).

Resistance to a practice of 'empathy' that colonises the other and limits the imagination (Britzman 1998) of the empathiser will most probably take the empathiser out of their comfort zone. The empathiser will only endure the discomfort if they are willing to make an emotional investment in a positive outcome, namely a better understanding of the other in a non-colonising way and a broadening and rich experience for themselves (see Bogdan, Cunningham \& Davies 2000:495). It is about caring enough to make an unsettling choice. Taylor (2007:307) calls caring 'the antidote to indifference'. This kind of personal engagement with the other is fully respectful of their alterity. Constant self-reflection is needed in order to remain aware of the temptation of identification and colonising the other's experience. The latter would amount to false empathy or 'egocentric projection'. Real empathy is an 'ethical relation of reflexive attention' (Taylor 2007:308). Real empathy is not possible when people refuse to empathically step out of their ethnocentric interpretive frameworks (McWilliams 2000:253-257), their cultural particularism and their pretentions that the way they interpret things is the way they are. This kind of attitude perpetuates 'institutionally sanctioned ignorance', which has to be challenged if real empathy was to be possible (Taylor 2007:309). The empathisers have the responsibility to recognise their own epistemic and hermeneutic frameworks as partial and insufficient. They should always be aware that these can get in the way of proper empathy.

The story of the other can make authentic 'feeling into' difficult for the empathiser. The self-critical listener who is able to remain suspicious of their own limited frameworks, knowledge and imagination will want to broaden their framework in order to not only observe and judge the story for its credibility, but also become a witness who is actively and ethically engaged (Taylor 2007:310-311). The listener not only aims to understand accurately, but also listens 'for implication and call'. The result is more than understanding. A relation has been forged and critical, affectively engaged dialogue becomes possible (see Britzman 1998:92-94). Such a mode of empathy resists hegemony of any sort.

Mature empathy does not come naturally. It requires willingness, dedication and knowledge not only about the particular process of emotional interaction between the subjects, but also about the larger systemic communicative processes that operate between them (Schertz 2007a: 185-186; see Schertz 2007b:165-178). Empathy as a form of 
communication is not only about transferring feelings, but is also about interaction and dialogue across boundaries. As a communicative process, empathy makes it possible for people to share feeling states and subjectivities. For Nussbaum (1995), passive empathy is sufficient for ethical reflection and understanding the experiences of others. Boler (1999:157) criticises this idea and cautions that empathy can be used as a form of social control to create the 'docile body' (see Foucault 1991). Schertz (2007a:186-188) does not agree with either the limited or the negative view of empathy, but sees it as potentially liberating. For liberation to occur, a definite 'shift in power relations' is required. According to him, the sharing of feeling states can stimulate growth and transformation in society. The sharing of real emotion can challenge the world view of the empathiser if that person is willing to engage in a selfreflective way with the issues of social justice that the experience of the other has brought to the fore.

The question that summarises the dilemma of the longstanding debate on empathy is, for Schertz (2007a:189-190), whether human beings are inherently inter-subjective or inherently separate. If inherently separate, the only access to the emotional experiences of the other would be through imagination or projection. If the self is seen as inherently inter-subjective, it is not about projecting the self or imagining into the other's experience, but rather about participating in the affective field that is produced by the encounter. This self is not separate, but is also not without boundaries. It is a complex mix of own, separate aspects and shared social experiences and relatedness (see Stern 1985:7-11). If the self is understood as relational, empathy can be redefined as the sharing of emotional information within a systemic communicative process. Empathy is then an aspect of human interaction. The other's behaviour, attitudes and expressions are not transferred as bits of information, but as an experience. Empathy can be seen as a primary condition of human intersubjectivity (Schertz 2007a:190). Human beings are part of a large inter-subjective communicative field in which both the cognitive and the affective play a role in a fluid process of interpersonal engagement. This engagement can also be a moral experience, because moral issues can surface and call for moral choices and action. In this " between" among persons', as Kennedy (1999:340) calls it, this liminal space, boundaries are at risk. Dialogue is the experience of lived difference. The engagement with and understanding of others who are different presents an opportunity for growth.

\section{Mature empathy and religion}

When in our 'age of resistance' against imperialism, the abuse of power, and injustice, all of which constitute 'a good cause' aimed at 'the common good', these good intentions go awry, it is as always the 'little people' in whose interest the protest actions were supposed to be, who get hurt and struggle to recoup their losses. Resistance needs empathy and empathy can serve resistance by making it more humane than it often is.
Proper empathy does not only focus solely on the self, but also on the other. An other-oriented perspective requires effort and self-regulation, the willingness to cross boundaries, to move out of one's comfort zone. It requires caring enough to make this unsettling choice and engage with the other in all their otherness, while always remaining self-critically selfaware. The question is where the motivation for such an emotional investment in the other without gain for the self would come from.

Religion has long been associated with altruism, doing good deeds without expecting any reward (Midlarsky, Mullin \& Barkin 2014:138; see Neusner \& Chilton 2005; Norenzayan \& Shariff 2008). In Christianity, such an attitude is central to the teachings and deeds of Jesus. While religion should help people to achieve altruism, human beings are intrinsically egotistic. That is the human condition (' $\sin ^{\prime}$ in religious language, the 'id' in the language of Freud). However, Comte ([1852]1966), who coined the term 'altruism', regarded human beings as innately altruistic. In unity with 'the Great Being', their goal would be to live for others (see Midlarsky et al. 2014:139). Many religious groups propagate the idea that the common good should take precedence over the interests of the individual (see Bower 1995).

Empathy (see Davis 1996; Hoffman 2000) and moral judgement (see Eisenberg 2000:665-697) have been identified as two possible motives for altruism. If a good deed is done out of empathy or moral judgement and the focus is entirely on the good of the recipient, it is considered altruistic. The overlap between empathy and altruism lies in one of the four components of empathy distinguished by Davis (1996), namely empathic concern. In the other three, personal distress (the discomfort of the empathiser), the ability to understand the situation of the other (perspective taking) and fantasy empathy, egotism is more central.

In exploring whether a higher level of moral maturity will lead to a more altruistic motive for providing help, the question of researchers is not 'whether people at higher stages of moral development help more, but rather the extent to which their helping is altruistic rather than egotistic' (Midlarsky et al. 2014:143-144). Altruism is part of what is called 'prosocial behaviour' (see Midlarsky et al. 2014:146), which includes a variety of forms of helping others. Not all prosocial behaviour can necessarily be ascribed to altruism. The motivation for 'doing good' can also be egotistic. However, altruism, a sub-category of prosocial behaviour, is not egotistic. The cost of altruism, which can include death, is high and there are not necessarily any gains for the individual (see Midlarsky et al. 2014:140-141).

Most of the world's religions encourage people to do good to others without expecting anything back. However, not only religious people do good to others and not all people who help others are necessarily religious (see Batson, Schoenrode \& Ventis 1993; Hood, Hill \& Spilka 2009; Spilka et al. 2003). Studies have shown some, though not always high, 
correlation between religiousness and helping behaviour. In some studies, on the other hand, religious people not only reported high altruism and empathy about themselves, but were also perceived so by peers (see Saroglou et al. 2005). According to Midlarsky et al. (2014:145), people who report religious experiences do tend to have a more positive attitude towards others and are more inclined to altruistic behaviour and providing help. However, religion can also have a negative effect when it blocks empathy for those who go against one's religious beliefs (see Jackson \& Esses 1997). There is a need for 'a universally compassionate religious style in which people in need are helped regardless of their belief system' (Midlarsky et al. 2014:145; see Batson et al. 2001).

Such a universally compassionate religious style can be found in the attitude of Jesus of Nazareth whose teachings were applied by Paul, the first 'Christian' biblical author, to practical life in the difficult and violent context of first century Palestine under the rule of the Roman empire. This subsequently became the ethics of Christianity.

\section{The ethics of Jesus}

A simple yet utterly difficult pronouncement attributed to Jesus is that of turning the other cheek after having experienced the violence of being slapped in the face (Mt 5:39; Lk 6:29). Paul applies this tradition in his context by saying that when the enemy attacks with fire, the believer should respond with love, because the powerful fire of love makes the enemy burn with shame ( $\operatorname{Rm} 12: 20)$.

What makes this attitude with regard to violence difficult for followers of Jesus is that, taken on face value, it seems as though a believer should accept the violent behaviour of the other passively and be the victim. However, as with most of Jesus' parables, it cannot be taken at face value, for there is a twist in the tale. In that cultural context, it had a much richer meaning. For a right-handed person (which most people are) to strike the other on the right cheek would mean having to use the back of the hand. In that culture, a blow with the back of the hand was a sign of disdain. The other was not regarded as an equal, because an equal at whom someone was angry would have been slapped with the palm of the hand on the left cheek. If the person who had been slapped with the back of the hand on the right cheek should turn the other cheek, that would mean forcing the violent other to treat them as an equal (see Van Aarde 2015:44). Malina (1993:12) points out that 'only equals can play the honour game of challenge and response'. Turning the other cheek would therefore not have been victim behaviour. The person will have taken charge of the situation and turned the tables on the one who thought he had the power, but did so in a non-violent way. This behaviour would then have broken the cycle of violence which would have been inevitable given the 'eye for an eye' mentality of human beings in general and that culture in particular.

'Blessed are the peacemakers for they will be called children of God', the Gospel of Matthew (5:9) reports Jesus saying.
Through a pragmatic reading of the text that focuses on the 'meaning-in context' (Bublitz \& Norrick 2011:4), the motives of the author and the affect elicited by the text, either intentionally or unintentionally, can be explored (see Huang 2011:397-424; McGinn 1989:83-84; Reed 1997:189-218). The context of this peace text in Matthew was anything but peaceful. The 'peace' of the Roman Empire, the 'pax Romana' was coerced by means of military power, oppression and violence when deemed necessary. Sociologist Michael Mann (1986:250-300) distinguishes four types of power that provoke resistance, namely military power, economic power, political power and 'imperial-theological' power.

Imperial-theological power is presented as God-given (see Crossan 2007:15-16). There were four possible ways of responding to this kind of power. The first was collaboration. The second was resistance which took the form of violence. Those who despised collaborators would retaliate both against the powers and their collaborators. The third option was the delayed gratification of projecting their vengeance onto the end-times. Justice will prevail when God's messiah will destroy the enemy. The fourth option was peaceful resistance. This is not pacifism or capitulation without resistance (see Van Aarde 2015). Rather, the aim of peaceful resistance is to very much resist the abuse of power and, if possible to stop the violence, but to do so in a non-violent way.

For Matthew, Jesus was the Messiah, the son of God and his followers were also 'children of God'. If God then regards the peacemakers as 'children of God', the implication is that they should be like Jesus (see Burridge 2007:48). Though Matthew does not use the word 'peace' often, the idea is central to his message, as is that of 'God-with-us', Immanuel, the Prince of Peace.

In Matthew's Palestine, Jerusalem and the temple had been destroyed and its valuables taken. Synagogues were becoming the location of religious authority and followers of Christ were coming together. This was a time of recovery. Villages were rebuilt under the leadership of the religious leaders (rabbi's). Matthew, the follower of Jesus, probably previously a rabbi (see Duling 2003:329-344), found himself in dispute with his former colleagues, the Pharisees. They had a different understanding of the will of God. They upheld the law of Moses, whereas the Jesus-followers adhered to the new law of the new Moses (see Donaldson 1985:203-213; France 2007:157). Though the followers of Jesus thought they understood what Jesus' perspective on the will of God required of them, the question was whether they were able to do it (Mt 7:21). If not, they were no better than the Pharisees (Mt 5:20). This ethic consisted of loving God, a love which should manifest in loving others (Mt 22:34-40). These others (the neighbour) included those one would not to want to love, but would rather regard as 'the enemy' (Mt 5:43-48).

Peace for Matthew was neither collaboration nor capitulation. He knew full well that the lives of those peacemakers who do 
not capitulate before violence would be touched by violence (the cross). They would be 'those who mourn', because that is the fate of the peacemakers, but they would also be comforted by the assurance that they were children of God.

Paul interpreted and applied Jesus' ethics to real life. According to Jewett, Paul's discourse on love in Romans 12:9-21, which Van Aarde (2012:45) calls 'Paul's version of turning the other cheek', should be regarded as transformative. He explains it as follows: 'Even a cup of water given to the thirsty becomes a means of expressing the love of Christ and thus extending the realm of divine righteousness' (Jewett 2007:779). Jesus-followers are called to an ethics of nonviolence in response to violent actions from others. That call is no less valid today.

\section{Conclusion: Mature empathy and mature spirituality}

Paul develops his ethics on non-violence and tolerance in line with how he understands the Jesus-tradition (Van Aarde 2012:49). Violence takes many forms, from direct and overt to hidden and subtle, from individual to systemic. In all its forms and on all levels of intensity, it is dehumanising and deprives people of their dignity and freedom (see KirkDuggan 2006:2). It harms all levels of humanity: physical, psychological, emotional, mental, social and spiritual. It can be perpetrated on a personal, political, religious, economic, ethnic, sexual and gender level. It is expressed through different means, from the personal to the public, through the media and social media.

Paul's own ethical life was a work in progress. In his early work (1 Th), 'he portrays himself as a powerless victim filled with rage' (Van Aarde 2012:54). In Aristotle's Rhetorica, well known in Paul's time, retribution would be warranted if deprived of one's dignity and worth, treated with contempt or malice, or having been insulted. The opposite would be friendship. Those who suffer humiliation should take courage in their 'friendship' in Christ (see Van Aarde 2012: 56-57). In Galatians, Paul reflects on faith that should act in love, though he still has memories of his earlier anger. Nevertheless, he proclaims God's mercy to the Galatians and reminds them that God called and loved them and that Christ gave his life for them (Van Aarde 2012:58). In Philippians (3:4-16), he aspires to become a new person 'in Christ' through faith. That would not be his own achievement (Van Aarde 2012:57), but the grace of God.

Love, according to 1 Corinthians 13, is eternal, not demanding, jealous or selfish. It does not hold a grudge, but is tolerant. It does not place the other under an obligation. It does not demand to be loved in return. According to Van Aarde (2012:58-59), 'it can exist only as a spontaneous emotion and as a spontaneous deed. However, it asks all, because it is shared in its totality' with the other. Limited love is human. Unlimited love is only possible when God's love flows through human beings. Paul's level of tolerance increased gradually until, in his last letter, Romans, he could fully adopt and internalise Jesus' ethic of 'turning the other cheek' (Van Aarde 2012:48).

In Romans, a life in faith is one lived 'with full commitment and total dedication to God' (Van Aarde 2012:59). The gifts of the Spirit, of which love is the greatest, should be of benefit to all people. Romans 12 provides guidelines for interpersonal relations. People should bless rather than curse one another (Rm 12:14), should live in unity rather than divided (Rm 12:16), should not repay evil with evil ( $\mathrm{Rm} 12: 17)$ and should

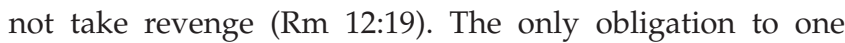
another should be love ( $\mathrm{Rm}$ 12:8). Coming into right relationship with God is what inspires to a totally new way of life in the dispensation of the Spirit (see Van Aarde 2012:60; Vos 2005:103).

In Paul's journey to spiritual maturity, a distinct development, a change in attitude, a 'metamorphosis' (see $\operatorname{Rm} 2: 2$ ) and a radical change in his way of thinking can be detected. Van Aarde (2012:61) explains this change as follows: 'It appears that tolerance has been given a new definition, because "hope" has been internalised'. For Chilton (2004:265), this kind of change is possible if a person is able to care as God cares and Christ resides in their innermost being. This is not the result of human endeavours, but can only be attributed to the power of God. Such a metamorphosis is about a different way of thinking than before and doing what is good in God's eyes. Those who have been transformed will answer evil with what is good, which Van Aarde (2012:63) calls Paul's version of Jesus' turning the other cheek. Paul 'internalised the "new life" of peace, joy and gratitude, the fruits of the Holy Spirit', not as his own achievement but as God-given grace (see Van Aarde 2012:66). His ability as a person of mature empathy and mature spirituality to turn the other cheek was the result of transformation which, in turn, was the result of a journey of development to a new way of thinking, namely the way of love. Paul's journey illustrates empathy as interactional knowing, with the potential for constructive resistance and human flourishing. It demonstrates a high level of moral maturity, which is not contaminated by egotism or egotistic altruism. This way of love resists all evil, oppression and injustice, and has the power to break the spiral of violence.

\section{Acknowledgements Competing interests}

The author declares that she has no financial or personal relationships which may have inappropriately influenced her in writing this article.

\section{References}

Aragno, A., 2008, 'The language of empathy: An analysis of its constitution, development, and role in psychoanalytic listening', Journal of the American Psychoanalytic Association 56(3), 713-740.

Arlow, J., 1979, 'The role of empathy in the psychoanalytic process', Bulletin of the Association of Psychoanalytic Medicine 18, 64-69. 
Bachrach, H.M., 1976, 'Empathy', Archives of General Psychiatry 33, 35-38.

Basch, M.F., 1983,' Empathic understanding: A review of the concept and some theoretical considerations', Journal of the American Psychoanalytic Association 31(1), 101-126.

Batson, C.D., Eidelman, S., Higley, S. \& Russel, S., 2001, “'And who is my neighbor?" Quest religion as a source of universal compassion', Journal for the Scientific Study of Religion 40, 39-50.

Batson, C.D., Lishner, D.A., Carpenter, A., Dulin, L., Harjusola-Webb, S., Stocks, E.L. et al., 2003, "As you would have them do unto you": Does imagining yourself in the other's place stimulate moral action?', Personality and Social Psychology Bulletin 29, 1190-1201.

Batson, C.D., Schoenrode, P. \& Ventis, W., 1993, Religion and the individual, Oxford University Press, New York.

Beres, D. \& Arlow, J.A., 1974, 'Fantasy and identification in empathy', Psychoanalytic Quarterly 43, 26-50.

Blechner, M.J., 1988, 'Epistemology: Ways of knowing in psychoanalysis', Contemporary Psychoanalysis 24(2), 301-310.

Bogdan, D., Cunningham, J.E. \& Davies, H.E., 2000, 'Reintegrating sensibility: Situated knowledge and embodied readers', New Literary History 4(31), 459-499.

Boler, M., 1999, 'The risks of empathy: Interrogating multiculturalism's gaze', in M. Boler (ed.), Feeling power: Emotions and education, pp. 155-174, Routledge, New York.

Bower, B., 1995, 'Return of the group', Science News 148(21), 328-330. https://doi. org/10.2307/4018279

Britzman, D., 1998, Lost subjects, contested objects: Toward a psychoanalytic inquiry of learning, State University of New York Press, Albany, NY

Bublitz, W. \& Norrick, N.R., 2011, 'Introduction: The burgeoning field of pragmatics', in W. Bublitz \& N.R. Norrick (eds.), Foundations of pragmatics, vol. 1, pp. 1-20, De Gruyter, Berlin.

Buie, D.H., 1981, 'Empathy: Its nature and limitations', Journal of the American Psychoanalytic Association 29, 281-307.

Burridge, R.A., 2007, Imitating Jesus: An inclusive approach to new testament ethics, Eerdmans, Grand Rapids, MI.

Buttelli, F.G.K. \& Le Bruyns, C., 2017, '\#FeesMustFall as social movement and emancipatory politics? Moving towards an apocalyptic theological praxis outside the limits of party politics', HTS Teologiese Studies/Theological Studies 73(3), a4789. https://doi.org/10.4102/hts.v73i3.4789

Chilton, B., 2004, Rabbi Paul: An intellectual biography, Doubleday, New York.

Comte, A., [1852] 1966, Catechism positivistic, Flammarion, Paris.

Coplan, A., 2011, 'Will the real empathy please stand up? A case for a narrow conceptualization', The Southern Journal of Philosophy 49, 40-65.

Crossan, J.D., 2007, God and empire: Jesus against Rome, then and now, HarperCollins, San Francisco, CA.

Davis, M.H., 1996, Empathy: A social psychological approach, Avalon, New York.

Decety, J., 2006, 'Human empathy', Japanese Journal of Neuropsychology 22, 11-33.

Decety, J. \& Lamm, C., 2009, 'Empathy versus personal distress: Recent evidence from social neuroscience', in J. Decety \& W. Ickes (eds.), The social neuroscience of empathy, pp. 199-213, MIT Press, Cambridge, MA

Deonna, J.A., 2007, 'The structure of empathy', Journal of Moral Philosophy 4(1), 99-116. https://doi.org/10.1177/1740468107077385

De Waal, F., 2009, The age of empathy: Nature's lessons for a kinder society, Penguin Random House, New York.

Donaldson, T.L., 1985, Jesus on the mountain: A study in Matthean theology, JSOT Press, Sheffield.

Duling, D.C., 2003, The new testament: History, literature, and social context, Thomas Wadsworth, Belmont, CA.

Eisenberg, N., 2000, 'Emotion, regulation, and moral development', Annual Review of Psychology 51, 665-697.

Ferenczi, S., [1928]1980, Final contributions to the problems and methods of psycho-analysis, Brunner/Mazel, New York.

Fliess, R., 1942, 'The metapsychology of the analyst', Psychoanalytic Quarterly 11, 211-227.

Foucault, M., 1991, Discipline and punish: The birth of the prison, Vintage Books, New York.

France, R.T., 2007, The Gospel of Matthew, Eerdmans, Grand Rapids, MI.

Freud, S., 1913a, 'On beginning treatment', Standard Edition 12, 147-156.

Freud, S., 1913b, 'The claims of psycho-analysis to scientific interest', Standard Edition $13,165-190$

Furer, M., 1967, 'Some developmental aspects of the superego', International Journal of Psychoanalysis 48, 277-280.

Hodges, S.D. \& Wegner, D.M., 1997, 'Automatic and controlled empathy', in W. Ickes (ed.), Empathic accuracy, pp. 311-339, Guilford Press, New York.

Hood, R.W., Hill, P.C. \& Spilka, B., 2009, The psychology of religion: An empirical approach, 4th edn., Guilford, New York.

Hoffman, M.L., 2000, Empathy and moral development: Implications for caring and justice, Cambridge University Press, Cambridge/New York.
Huang, Y., 2011, 'Types of inference: Entailment, presupposition, and implicature', in W. Bublitz \& N.R. Norrick (eds.), Foundations of Pragmatics, vol. 1, pp. 397-424, De Gruyter, Berlin.

Jackson, L. \& Esses, V., 1997, 'Of scripture and ascription', Personality and Social Psychology Bulletin 23, 893-906.

Jackson, P.L., Brunet, E., Meltzoff, A.N. \& Decety, J., 2006, 'Empathy examined through the neural mechanisms involved in imagining how I feel versus how you feel pain', Neuropsychologia 44, 752-761.

Jewett, R., 2007, Romans: A commentary, Fortress, Minneapolis, MN. (Hermeneia: A Critical and Historical Commentary on the Bible.)

Kennedy, D., 1999, 'Philosophy for children and the reconstruction of philosophy', Metaphilosophy 30(4), 338-359.

Kirk-Duggan, C.A., 2006, Violence and theology, Abingdon, Nashville, TN.

Kohut, H., 1971, The analysis of the self, International Universities Press, New York.

Langer, S.K.., 1967, Mind: An essay on human feeling, vol. 1, Johns Hopkins Press, Baltimore, MD.

Lipps, T., 1913, Zur Einfühlung, Engelmann, Leipzig.

Malina, B.J., 1993, Windows on the world of Jesus: Time travel to ancient Judea, Westminster John Knox, Louisville, KY.

Mann, M., 1986, The sources of social power, Vol. 1: A history of power from the beginning to $A D$ 1760, Cambridge University Press, Cambridge, MA.

McGinn, M., 1989, Sense and certainty: A dissolution of scepticism, Basil Blackwell, London.

McWilliams, S., 2000, 'Trajectories of change: The politics of reading postcolonial women's texts in the undergraduate classroom', in A. Amireh \& L.S. Majaj (eds.), Going global: The transnational reception of third world women writers, pp. 252-283, Garland, New York/London.

Midlarsky, E., Mullin, A.S.J. \& Barkin, S.H., 2014, 'Religion, altruism, and prosocial behaviour: Conceptual and empirical approaches', in L.J. Miller, The oxford handbook of psychology and spirituality, pp. 138-148, Oxford University Press, Oxford.

Modell, A., 1979, 'Empathy and the failure of empathy', Association for Psychoanalytic Medicine Bulletin 18, 70-74

Morton, N.K., 1977, 'Beloved image!', paper delivered at the national conference of the American academy of religion, San Francisco, California on December 28 the Am.
1977.

Neusner, J. \& Chilton, B., 2005, Altruism in world religions, Georgetown University Press, Washington, DC

Norenzayan, A. \& Shariff, A.F., 2008, 'The origin and evolution of religious prosociality', Science 322(5898), 58-62.

Nussbaum, M.C., 1995, Poetic justice, Beacon, Boston, MA.

Preston, S.D. \& De Waal, F.B., 2002, 'Empathy: Its ultimate and proximate bases', Behavioral and Brain Sciences 25(1), 1-20.

Reed, J.T., 1997, 'Discourse analysis', in S.E. Porter (ed.), A handbook to the exegesis of the new testament, pp. 189-218, Brill, Leiden.

Ruby, P. \& Decety, J., 2001, 'Effect of subjective perspective taking during simulation of action: A PET investigation of agency', Nature Neuroscience 4, 546-550.

Saroglou, V., Pichon, I., Trompette, L., Verschueren, M. \& Dernelle, R., 2005, 'Prosocial behaviour and religion', Journal for the Scientific Study of Religion 44, 323-348.

Schertz, M., 2007a, 'Avoiding "passive empathy" with philosophy for children', Journal of Moral Education 36(2), 185-190.

Schertz, M., 2007b, 'Empathy as intersubjectivity: Resolving Hume and Smith's Divide', Studies in Philosophy and Education 26(2), 165-178.

Schwaber, E.A., 1984, 'Empathy: A mode of psychoanalytic listening', in J. Lichtenberg, M. Bornstein \& D. Silver (eds.), Empathy, vol. 2, pp. 143-185, Analytic Press, Hillsdale, NJ.

Shapiro, T., 1981, 'The development and distortion of empathy', Psychoanalytic Quarterly 43, 4-25.

Shevrin, H., 1978, 'Semblance of feeling in the imagery of affect in empathy, dreams and unconscious processes: A revision of Freud's several affect theories', in S. Smith (ed.), The human mind revisited, pp. 263-294, International Universities Press, New York.

Spilka, B., Hood, R.W., Hunsverger, B. \& Gorsuch, R., 2003, The psychology of religion: An empirical approach, Guilford, New York.

Spivak, G.C., 1996, 'How to teach a "culturally different" book', in D. Landry \& G. Maclean (eds.), The spivak reader, pp. 237-266, Routledge, London.

Stern, D.B., 1994, 'Empathy is interpretation (and whoever said it wasn't?): Commentary of papers by Hayes, Kiersky and Beebe, and Feiner and Kiersky', Psychoanalytic Dialogues 4, 441-471.

Stern, D.N., 1985, The interpersonal world of the infant: A view from psychoanalysis and developmental psychology, Basic Books, New York.

Stueber, K.R., 2006, Rediscovering empathy: Agency, folk psychology, and the human sciences, MIT Press, Cambridge, MA.

Sullivan, H.S., 1953, The interpersonal theory of psychiatry, W.W. Norton, New York.

Taylor, L.K., 2007, 'Reading desire: From empathy to estrangement, from enlightenment to implication', Intercultural Education 18(4), 297-316.

Titchener, E., 1909, Experimental psychology of thought processes, MacMillan, New York. 
Van Aarde, A.G., 2012, 'Paul's version of "turning the other cheek": Rethinking violence as tolerance', in P.G.R. De Villiers \& J.W. Van Henten (eds.), Coping with violence in the new testament, pp. 43-67, Brill, Leiden.

Van Aarde, A.G., 2015, 'Vredemakers as Kinders van God (Matt 5:9): ‘n Pragmaties linguistiese lesing/peacemakers as children of God (Mt 5:9): A pragmaticlinguistic reading', HTS Theological Studies 71(1), Art. \#2935, 9 pages. https://doi. org/10.4102/hts.v71i1.2935

Verducci, S., 2000, 'A conceptual history of empathy and a question it raises for moral education', Educational Theory 50, 63-80.
Vos, J.S., 2005, De betekenis van de dood van Jezus: Tussen seculiere exegese en christelijke dogmatiek (The meaning of the death of Jesus: Between secular exegesis and Christian Dogmatics), Meinema, Zoetermeer.

Webster's New World Dictionary, 1966, Pathetic fallacy, World Publishing, Cleveland, $\mathrm{OH}$.

Weigert, E., 1962, 'Sympathy, empathy and freedom in therapy', in L. Salzman \& J.H. Masserman (eds.), Modern concepts of psychoanalysis, pp. 143-159, Philosophical Library, New York. 